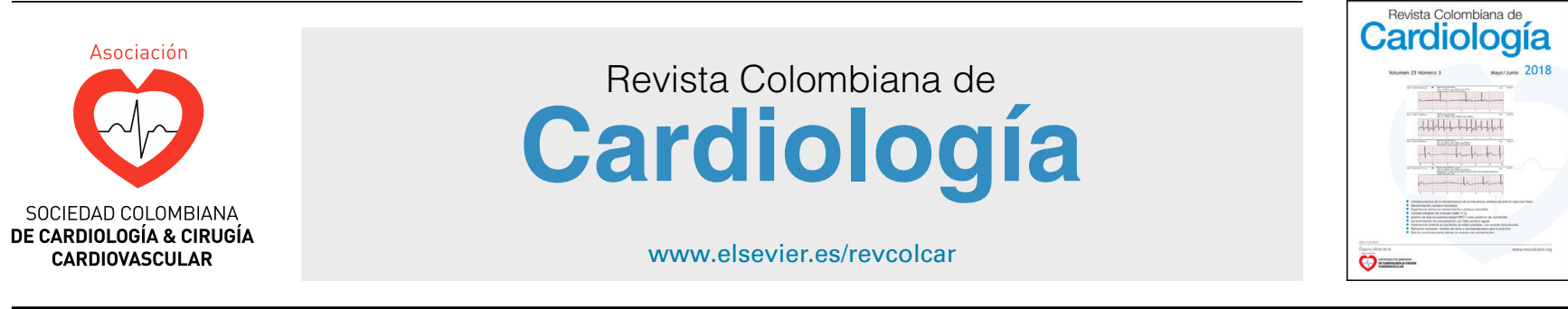

ADULT CARDIOLOGY - ORIGINAL ARTICLES

\title{
Analysis of morbid obese women aerobic potential
}

\section{Renato V. Linhares ${ }^{\mathrm{a}, \mathrm{b}, \mathrm{c}, \mathrm{d}, \mathrm{e}, *}$, Felipe M.M. Rosa ${ }^{\mathrm{b}}$, José C. Quaresma ${ }^{\mathrm{c}, \mathrm{d}}$, Fábio A. Castilha $^{\mathrm{a}, b, \mathrm{~d}}$, João R.I. Carneiro ${ }^{\mathrm{b}}$, Valeria B. Braulio ${ }^{\mathrm{b}, c, \mathrm{~d}}$, José Fernandes Filho ${ }^{\mathrm{a}, \mathrm{b}, \mathrm{c}}$, Denise P. Carvalho ${ }^{d}$}

\author{
a Laboratory of Human Movement Biosciences (LABIMH), Rio de Janeiro, RJ, Brazil \\ b Clementino Fraga Filho Universitary Hospital - Federal University of Rio de Janeiro, RJ, Brazil \\ c Laboratório de Nutrologia (Labonutro), Universitary Hospital - Federal University of Rio de Janeiro, RJ, Brazil \\ ' Federal University of Rio de Janeiro, RJ, Brazil \\ e Research Group on Human Science of Colégio Pedro II, RJ, Brazil
}

Received 1 August 2018; accepted 15 October 2018

Available online 19 December 2018

\section{KEYWORDS \\ Women; \\ Morbid obesity; \\ 6-minute walk test; \\ Maximum stress test; \\ Physical fitness}

\begin{abstract}
Introduction: nowadays, with the increase of world obesity and the numbers of morbidly obese people, a concerning public health problem that is difficult to solve rises up.

Objective: to analyse the physiological responses after the 6-minute walk tests and maximum stress test in the arm cycle ergometer in morbidly obese pre-bariatric surgery women.

Methods: fifteen level III obesity women aged $35.6 \pm 6.6$ years took part in this experiment. Firstly, they went through an anamnesis and body composition analysis; secondly, they were submitted to a 6-minute walk test and a maximum stress test in arm cycle ergometer on alternate days.

Results: patients were able to perform the maximum stress test and showed better aerobic potentials in the arm cycle ergometer than in the 6-minute walk test. No significant differences were found between $\mathrm{SPO}_{2}$ and diastolic blood pressure between the moments of rest and after the tests, neither in the systolic blood pressure after the 6-minute walk test and the values of rest and post 5 minutes in the maximum stress test. The main differences found were between the maximum systolic blood pressure in the cycle ergometer test and the other moments and the heart rate after the tests and the heart rate at rest.

Conclusion: the maximum stress test in arm cycle ergometer is a safe method that allows greater requirement and control applied to the heart system than in the 6-minute walk test. In addition, it allows the development of a more individualized aerobic training and prescription of aerobic physical exercise program.

(c) 2018 Sociedad Colombiana de Cardiología y Cirugía Cardiovascular. Published by Elsevier España, S.L.U. This is an open access article under the CC BY-NC-ND license (http:// creativecommons.org/licenses/by-nc-nd/4.0/).
\end{abstract}

\footnotetext{
* Corresponding author.

E-mail address: renatolinharesjf@gmail.com (R.V. Linhares).
} 


\section{PALABRAS CLAVE}

Mujeres;

Obesidad mórbida;

Prueba de caminata

de 6 minutos;

Prueba de esfuerzo

máximo;

Aptitud física

\section{Análisis del potencial aeróbico de obesas mórbidas}

\section{Resumen}

Introducción: Actualmente, con el aumento de la obesidad en el mundo y del número de obesos mórbidos se evidencia un problema de salud pública de difícil resolución.

Objetivo: analizar las respuestas fisiológicas, tras las pruebas de caminata de 6 minutos y de esfuerzo máximo en cicloergómetro de brazos, en obesas mórbidas precirugía bariátrica.

Métodos: se evaluaron 15 mujeres con obesidad grado III con edad media de 35,6 $\pm 6,6$ años, las cuales participaron inicialmente de una anamnesis con el análisis de la composición corporal y posteriormente participaron en días alternos de la prueba de 6 minutos de caminata y del mismo, prueba de esfuerzo máximo en cicloergómetro de brazos.

Resultados: las pacientes lograron realizar la prueba de esfuerzo máximo y demostraron mejores potenciales aeróbicos en el cicloergómetro de brazos que en la prueba de caminata. No se encontraron diferencias significativas entre la $\mathrm{SPO}_{2}$ y la presión arterial diastólica entre los momentos de reposo y después de las pruebas y también en la presión arterial sistólica posterior a la prueba de caminata y los valores de reposo y después de 5 minutos en la prueba de esfuerzo máximo. Las principales diferencias se observaron entre la presión arterial sistólica máxima en la prueba en cicloergómetro y los otros momentos y en la frecuencia cardiaca después de las pruebas y las frecuencias cardiacas en reposo.

Conclusión: la prueba de esfuerzo máximo en cicloergómetro de brazos es un método seguro que posibilita mayor exigencia y control aplicado al sistema cardíaco que en la prueba de caminata. Adicionalmente, permite un programa de entrenamiento y una prescripción del ejercicio físico aeróbico más individualizados.

(C) 2018 Sociedad Colombiana de Cardiología y Cirugía Cardiovascular. Publicado por Elsevier España, S.L.U. Este es un artículo Open Access bajo la licencia CC BY-NC-ND (http:// creativecommons.org/licenses/by-nc-nd/4.0/).

\section{Introduction}

Nowadays, there is a worldwide increase in obesity, even in the share of the considered severe or morbid groups, ${ }^{1}$ considered one of the most complicated public health problems to solve ${ }^{2}$ since the disease is associated with comorbidities such as the increasing number of obesity related to cardiovascular risks cases.

Among the obese, there are those with higher levels, that is, with the body mass index above 40 , considered to be at level III or morbidly obese, who usually present a low physical fitness characteristic ${ }^{4}$ and lack of concern about the effects of a physical exercise program over body composition and other body systems when undergoing gastric bypass surgery. ${ }^{5}$ This issue comes to light the need and importance of researching and building up adequate physical tests for the population with a high obesity level so that a greater control of the physical exercise can be allowed and consequently the observation of its effects on the body and cardiovascular variables changes.

Another characteristic of the morbid obese is related to the low physical fitness ${ }^{6}$ and the few studies on the physical effects of a physical exercise program, ${ }^{7}$ which leads to the need of researches that allow the monitoring and control of cardiovascular variables in effort.

One of the most common methods for evaluating the cardiorespiratory fitness is the 6-minute walk test (6MWT), sendo um dos mais comuns para avaliações funcionais e de potencial aeróbico, which has been applied in patients with heart failure ${ }^{8}$ obese $^{9}$ among others, allowing the understanding of an individual's breathing, cardiac and metabolic state, ${ }^{10}$ besides being inexpensive and relatively simple to apply. ${ }^{11}$ It has limitations ${ }^{12}$ and it is not necessarily the best method for clinical follow-up of functional capacity ${ }^{13}$ once it does not show confidence in long-term exercise analysis. ${ }^{14}$

Therefore, an ergospirometric test, which is considered to be the gold standard method, ${ }^{15,16}$ would be an appropriate way to analyse the cardiorespiratory, metabolic and muscle systems stress responses, ${ }^{17}$ thus allowing an individualized prescription of the submaximal aerobic training, which according to Cerrone et al. ${ }^{18}$ is of great importance in obese research, since this population performs activities of relatively low intensity in their daily lives.

However, because of the difficulty in balance and maintaining activities due to the excess weight they need to support, the use of the cycle ergometer in morbid obese people is an alternative, since it allows analysing the muscle work during the physical exercise, ${ }^{19}$ besides allowing the use of cranks for arm exercise, thus facilitating the applicability of the maximum stress test in such population.

Therefore, the objective of this study was analysing the responses of heart rate, blood pressure and oxygen saturation after the 6-minute walk tests and maximum stress on the arm cycle ergometer in obese morbid pre-bariatric surgery women. 


\section{Materials and methods}

\section{Sample and procedures}

The sample from this research was chosen by convenience, and made up of 15 sedentary women, aged between 25 and 51 years-old, who were part of the Bariatric Surgery Program from the University Hospital Clementino Fraga Filho, Federal University of Rio de Janeiro, RJ, Brazil (PROCIBA / HUCFFUFRJ). These women were not at menopause and were in the process of clinical, physiotherapy and physical evaluations for future bariatric surgery.

As exclusion criteria: patients over 60 years-old; with untreated hypothyroidism, cognitive alterations that would impede the protocols accomplishment; individuals classified as "active" according to IPAQ; pacemaker users; pregnant women; women with previous bariatric surgery; post-operation or infectious recovery; neoplasms in remission for over 5 years; patients under use of beta blocker medication; Diabetes Mellitus under insulin use; Autoimmune disease; and physical or neurological inability to walk.

Soon after the patients were authorized to take part in the physical tests, an anamnesis and the recommendations for undergoing the 6-minute walk test and the maximum stress exercise test on the arm cycle ergometer were conducted. The tests were performed on alternate days as a way of not interfering in the results.

The protocol used for the cycle ergometer was the Ramp one, by using the Shvartz \& Rabold ${ }^{20}$ formula for lower limbs cycle ergometer $\mathrm{VO}_{2}=40.31-(0.41 \times$ age $)$, being corrected for the use with upper limbs $(35 \%$ less than the $\mathrm{VO}_{2 \max }$ expected) considering the differences between the two ergometers. ${ }^{20,21}$ The results were inserted in the YMCA formula in order to calculate the maximum power in upper limb cycle ergometer $\mathrm{VO}_{2 \max }=\mathrm{W}_{\max } \times 18.36+$ (Weight $x$ 3.5). ${ }^{21}$ Subsequently, $50 \%$ of the estimated $W_{\max }$ was lowered, according to what foresees the III Guideline for the Brazilian Cardiology Society for Exercise Test ${ }^{22}$. The initial load was $30 \mathrm{~W}$ for all patients, minimum value accepted by the cycle ergometer, and the load increments were as minimum as possible in order to create a smooth and continuous fatigue. Only two patients had their ramp different from what was predicted: one exceeding twelve minutes and another one exceeding less than eight minutes, which shows the good applicability of the protocol.

Patients were instructed to maintain a rhythm between 70 and 90 cycles/rotations per minute (RPM), or to keep the rhythm as comfortable as possible, since the number of cycles did not influence the power. The HR, SPO2, SBP and DBP variables were checked in 5 different moments: at rest, just after the maximum stress, one minute, three and five minutes after the physical test. The calculation for maximum heart rate was predicted by using the formula MaxHR $=198-(0.42 \times$ age $)$ proposed by Sheffield et al. ${ }^{23}$.

The criteria used to classify the test as maximum were: $\mathrm{R}$ higher than 1.1; Heart Rate equal to or greater than $85 \%$ of MaxHR, and / or voluntary exhaustion. ${ }^{24-26}$ The criteria for interrupting the test followed the YMCA Guidelines for stress testing, by using absolute and relative indications.

\section{Instruments}

Blood pressure (BP) was checked by using a GLICOMED ${ }^{\circledR}$ heart stethoscope and a GLICOMED ${ }^{\circledR}$ sphygmomanometer
(Premium, Glicomed $^{\circledR}$ ). For checking the heart rate (HR) and oxygen saturation $\left(\mathrm{SPO}_{2}\right)$, a $\mathrm{CONTEC}^{\oplus}$ oximeter was used. The room was arranged adequately in order to guarantee the recommendations of the CAREFUSION calorimeter, model $V_{\text {Max }} 29 \mathrm{~N}$ Encore, which are: an environment with the minimum of noise and the maximum of three evaluators; a temperature between $20^{\circ}$ and $24^{\circ}$ Celsius and relative humidity between 50 and $60 \%$. In addition, a TECHNOGYM arm cycle ergometer, model EXCITE PRÓ, was used.

\section{Statistical analysis}

All research participants were volunteers, dully enrolled in the Obesity Program of the Clementino Fraga Filho Hospital, Federal University of Rio de Janeiro, RJ, Brazil, and have signed a Term of Free and Informed Consent, authorizing the research, which was conducted in accordance with the principles stated by the Declaration of Helsinki, Resolution 196/96 of the National Ethics and Research Council as well as its determinations in place. The present research was approved by the Ethics and Research Committee of the Federal University of Rio de Janeiro (CEO-HUCFF process 132-13 of group III), with no sponsorship or costs for the volunteers enrolled in the research.

Data analysis was performed under a descriptive statistical treatment, with means, standard deviation, minimum and maximum. Inferential statistics were used for analysis of the data, using a Variance Analysis, and for each comparison sequence, between the physiological variables (HR, DBP, SBP and $\left.\mathrm{SPO}_{2}\right)$ at rest and after the 6-minute walk test and maximum stress test, $\mathrm{p}<0.05$ was used as the significance level. When the difference was significant, the Scheffé test was performed. The significance level assumed was $5 \%$. In addition to this relationship between the two variables, itwas also verified that there was nocorrelation between theindividuals in the effort measured in the 6MWT and the found in the test of maximum effort (Table 1).

\section{Results}

Table 2 below shows the descriptive values of the distance expected in the 6-minute walk test and the distance reached, the metabolic equivalent (MET) and the relative and absolute oxygen volumes (Table 3 ).

\section{Discussion}

The analysis of the functional status and the cardiorespiratory level are important variables, since they are

Table 1 Mean, standard deviation, minimum and maximum of the anthropometry and body composition of the sample.

\begin{tabular}{llll}
\hline Variables & Mean \pm SD & Minimum & Maximum \\
\hline Age (years) & $35.6 \pm 6.6$ & 26.0 & 51.0 \\
Body mass $(\mathrm{kg})$ & $120.9 \pm 19.3$ & 91.2 & 151.6 \\
Height $(\mathrm{m})$ & $1.61 \pm 0.07$ & 1.50 & 1.72 \\
$\mathrm{BMI}\left(\mathrm{kg} / \mathrm{m}^{2}\right)$ & $46.0 \pm 4.0$ & 41.0 & 53.0 \\
WHR & $1.06 \pm 0.05$ & 0.99 & 1.19 \\
$\% \mathrm{~F}$ & $51.2 \pm 3.1$ & 43.1 & 55.8 \\
MM $(\mathrm{kg})$ & $33.2 \pm 5.2$ & 25.6 & 42.4 \\
\hline
\end{tabular}

$\mathrm{BMI}=$ body mass index; $\mathrm{WHR}=$ waist hip ratio; $M M=$ muscle mass. 
Table 2 Obesity aerobic power test results.

\begin{tabular}{llll}
\hline Variables & Mean \pm SD & Minimum & Maximum \\
\hline Distance Expected 6' (meters) & $516.0 \pm 37.32$ & 443 & 574 \\
Distance in 6' (meters) & $516.4 \pm 49.08$ & 400 & 585 \\
$\mathrm{MET} 6$ & $3.49 \pm 0.23$ & 2.91 & 3.80 \\
$\mathrm{VO}_{2}(\mathrm{ml} / \mathrm{kg} / \mathrm{min})(\mathrm{MST})$ & $13.00 \pm 2.69$ & 10.3 & 17.9 \\
$\mathrm{VO}_{2}(\mathrm{l} / \mathrm{min})(\mathrm{MST})$ & $1.50 \pm 0.20$ & 1.19 & 1.92 \\
\hline
\end{tabular}

MST = Maximum Stress Test; SD = standard deviation.

Table 3 Comparative results and mean values, standard deviation, minimum and maximum for the physiological variables.

\begin{tabular}{|c|c|c|c|c|c|c|c|c|c|}
\hline Variable & Rest 6' & Post 6' & Rest MST & Max. MST & Post MST & Post 3' MST & Post 5' MST & $\mathrm{F}$ & $\begin{array}{l}\mathrm{P} \\
\text { Value }\end{array}$ \\
\hline $\mathrm{SPO}_{2}$ & $\begin{array}{l}98.5 \pm 0.8 \\
(97-99)\end{array}$ & $\begin{array}{l}98.2 \pm 0.7 \\
(97-99)\end{array}$ & $\begin{array}{l}96.8 \pm 3.5 \\
(85-99)\end{array}$ & $\begin{array}{l}98.0 \pm 0.39 \\
(97-99)\end{array}$ & $\begin{array}{l}98.28 \pm 0.61 \\
(97-99)\end{array}$ & $\begin{array}{l}98.0 \pm 0.7 \\
(97-99)\end{array}$ & $\begin{array}{l}98.0 \pm 0.9 \\
(96-99)\end{array}$ & 1.999 & 0.073 \\
\hline DBP & $\begin{array}{l}83.2 \pm 6.4 \\
(76-100)\end{array}$ & $\begin{array}{l}86.5 \pm 4.2 \\
(80-92)\end{array}$ & $\begin{array}{l}83.2 \pm 8.0 \\
(64-96)\end{array}$ & $\begin{array}{l}83.7 \pm 9.1 \\
(57-94)\end{array}$ & $X X X$ & $\begin{array}{l}81.3 \pm 8.6 \\
(64-95)\end{array}$ & $\begin{array}{l}80.1 \pm 9.6 \\
(60-92)\end{array}$ & 1.225 & 0.305 \\
\hline SBP & $\begin{array}{l}126.9 \pm 13.9 \\
(110-150)\end{array}$ & $\begin{array}{l}143.4 \pm 9.4 \\
(130-160)\end{array}$ & $\begin{array}{l}126.4 \pm 11.7 \\
(100-142)\end{array}$ & $\begin{array}{l}157.4 \pm 23.6 \\
(114-200)\end{array}$ & $X X X$ & $\begin{array}{l}131.5 \pm 13.8 \\
(110-160)\end{array}$ & $\begin{array}{l}122.1 \pm 10.9 \\
(100-140)\end{array}$ & 13.147 & 0.000 \\
\hline HR & $\begin{array}{l}85.8 \pm 13.0 \\
(68-112)\end{array}$ & $\begin{array}{l}140.4 \pm 20.2 \\
(104-168)\end{array}$ & $\begin{array}{l}87.2 \pm 14.6 \\
(68-124)\end{array}$ & $\begin{array}{l}167.0 \pm 13.5 \\
(150-193)\end{array}$ & $\begin{array}{l}124.0 \pm 15.86 \\
(102-159)\end{array}$ & $\begin{array}{l}109.8 \pm 12.9 \\
(96-144)\end{array}$ & $\begin{array}{l}105.7 \pm 12.4 \\
(92-136)\end{array}$ & 60.584 & 0.000 \\
\hline
\end{tabular}

$\mathrm{DBP}=$ diastolic blood pressure; $\mathrm{F}=\mathrm{F}$-statistics; HR = heart rate; Rest 6' = rest before the 6-minute walk test; Post 6' $=$ After the 6-minute walk test; Rest MST = rest before the Maximum Stress Test; Post MST = After Minute Maximum Stress Test; Post 3' MST = After 3 minutes of the Maximum Stress Test; Post 5' MST = After 5 minutes of the Maximum Stress Test; Max MST = Maximum values in the Maximum Stress Test; SBP = systolic blood pressure.

"Significant difference $(\mathrm{p} \leq 0.05)$.

prerequisites for the risk stratification in the perioperative evaluation in non-cardiac surgeries, ${ }^{27,28}$ and allows the prescription of aerobic physical exercise and consequently the accompaniment of the physical improvement of people

Among the aerobic potential analysis tests, the 6-minute walk test is the most common in functional and cardiorespiratory evaluations in obese people, ${ }^{29,30}$ although it has some limitations. ${ }^{31}$ According to the 6 -minute test, it is possible to obtain the number of MET through the distances travelled by the individuals. Galandro et al. ${ }^{28}$, when analysing the physiological stress required by non-cardiac surgeries, report that bearing physical exercises that require up to 4-5 MET would be considered a good value. In this research, the morbidly obese patients in preoperative bariatric surgery stage, the mean value reached was 3.4 METS in the 6-minute walk test and in the maximum stress test in the arm cycle ergometer, which does not have to support all the body mass, the patients reached a relative $\mathrm{VO}_{2}$ average of 13.0 $\mathrm{ml} / \mathrm{kg} / \mathrm{min}$, which corresponds to $3.7 \mathrm{METS}$. In addition, the relative $\mathrm{VO}_{2}$ values found in the maximum stress test were lower than those found in the study with obese women on treadmill conducted by Thommazo-Luporini et al. ${ }^{32}$, and lower in the 6-minute walk test, which is understandable since there was a mean difference between the BMI.

In other words, the use of another evaluation protocol allowed the morbid obese women from this study to achieve better results in aerobic power potential; in addition, the arm cycle ergometer, which allows the analysis of ventilatory parameters such as oxygen consumption, ${ }^{33}$ showing that the results of the review study conducted by Loureiro et al. ${ }^{27}$ who compared several scales of perioperative risk and who had trouble defining which would be better for different populations, deserves to be better investigated in morbid obese women.

Another issue regarding the maximum stress test which needs to be highlighted is the possibility of allowing the electrical analysis of the heart, as despite the limitations in most of the scales analysed by Loureiro et al. ${ }^{27}$ with regards to perioperative risk scores, in most of them, along with the Guideline of the Brazilian Cardiology Society for Perioperative Evaluation, it's reported that changes in the electrocardiogram are points that deserve observation.

Regarding the physiological responses related to $\mathrm{HR}$, blood pressure (BP) and oxygen saturation $\left(\mathrm{SPO}_{2}\right)$, these are points that should be analysed in the physical exercise and physical exercise responses, since they assist in the prescription and control of physical exercise and are essential for an individualized training program ${ }^{34}$ and for the treatment of obesity. ${ }^{35}$

The oxygen saturation $\left(\mathrm{SPO}_{2}\right)$ allows the observation of hypoxemia, which is related to respiratory insufficiencies ${ }^{36}$ and other respiratory changes, ${ }^{37}$ including obese people, who have breathing problems related to the disease. ${ }^{38}$ When the comparative analysis was performed between the moments before and after the 6-minute walk tests and the maximum stress test, there were no significant differences and no patient has shown desaturation, evidencing the safety in its application.

Blood pressure (BP) is a major impact factor in obese people with a higher prevalence of hypertension than in healthy people, ${ }^{39}$ and therefore is one of the risk factors for heart problems. In this study, no significant differences in diastolic blood pressure (DBP) between rest and post-test moments were seen, but were in systolic blood pressure (SBP). These differences were mainly between the maximal SBP in the 
maximum stress test and the rest values, but not between the SBP post the 6-minute walk test and the one found at rest, and also after 5 minutes of the maximum stress test.

The heart rate (HR) gains importance in obese individuals by the high levels of morbidity and mortality due to cardiovascular diseases in this group of people, ${ }^{40}$ besides, it's a common way of prescribing individualized aerobic exercise, allowing such prescription in an appropriate training zone, as well as the possibility of checking the HR variability during the test, since the decrease of this variability has been demonstrated to be related to the increase in BMI. ${ }^{41}$

In the comparative analysis between the analysed HR moments, there were significant differences between the maximum heart rate in the maximum stress test $\left(H R_{\max }\right)$ and the heart rates at rest (HRR), and also the heart rate after the 6-minute walk test, which also differed significantly between the moments of rest. The results showed an increase in HR as the stress got higher, and a higher requirement of heart demand during the test.

It is concluded that the maximum stress test in a cycle ergometer is a safe, possible method that allows a greater requirement of the heart stress than in the 6-minute walk test, besides allowing a greater control of the cardiorespiratory stress through the monitoring of the electrocardiogram and consequently greater data gathering for pre-surgical risks analysis in bariatric surgeries. In addition, it allows a more individualized aerobic physical exercise prescription and the accompaniment of a physical training program. It is suggested that other studies are developed, including male samples, in addition to an analysis with a larger group of women, a fact that may be considered a limitation of this study and the analysis of an aerobic physical exercise program and its effects over morbid obese women as a weight loss program, in order to improve the quality of life and health levels of obese individuals.

\section{Conflict of interest}

None.

\section{References}

1. Lavie CJ, Milani RV, Ventura HO. Obesity and cardiovascular disease: risk factor, paradox, and impact of weight loss. J Am Coll Cardiol. 2009;53:1925-32.

2. Aranceta-Bartrina J, Pérez-Rodrigo C, Alberdi-Aresti G, RamosCarrera N, Lázaro-Masedo S. Prevalencia de obesidade general y obesidade abdominal en la población adulta española (25-64 años) 2014-2015: estudo ENPE. Rev Esp Cardiol. 2016;69:579-87.

3. Booth HP, Prevost AT, Gulliford MC. Severity of obesity and management of hypetension, hypercholesterolaemia and smoking in primary care: population-based cohort study. J Human Hypertension. 2016;30:40-5.

4. Stegen S, Derave W, Calders P, Van Laethem C, Pattyn P. Physical fitness in morbidly obese patients: effect of gastric bypass surgery and exercise training. Obes Surg. 2011;21:61-70.

5. Campanha-Versiani L, Pereira DAG, Ribeiro-Samora GA, Ramos AV, Diniz MFHS, De Marco LA, et al. The Effect of a Muscle Weight-Bearing and Aerobic Exercise Program on the Body Composition, Muscular Strength. Biochemical Markers, and Bone Mass of Obese Patients Who Have Undergone Gastric Bypass Surgery. Obesity Surgery. 2017;27:2129-37.

6. Stegen S, Derave W, Calders P, Van Laethem C, Pattyn P. Physical fitness in morbidly obese patients: effect of gastric bypass surgery and exercise training. Obes Surg. 2011;21:61-70.
7. Campanha-Versiani L, Pereira DAG, Ribeiro-Samora GA, Ramos AV, Diniz MFHS, De Marco LA, et al. The effect of a muscle weight-bearing and aerobic exercise program on the body composition, muscular strength, biochemical markers, and bone mass of obese patients who have undergone gastric bypass surgery. Obesity Surgery. 2017;27:2129-37.

8. Maldonado-Martin S, Brubaker PH, Eggbeen J, Stewart KP, Kitzman DW. Association between 6-minute walk test distance and objective variables of functional capacity after exercise training in elderly heart failure patients with preserved ejection fraction: a randomized exercise trial. Arch Phys Med Rehabil. 2017;98(3): 600-3.

9. Terra CMO, Simões CF, Mendes AA, Oliveira RP, Dada RP, Mendes VHS, et al. Relação entre nível de atividade física em lazer, antropometria, composição corporal e aptidão física de mulheres submetidas à cirurgia bariátrica e um grupo equivalente não operado. ABCD, Arq Bras Cir Dig. 2017; 30(4):252-255.

10. Li AM, Yin J, Yu CC, Tsang T, So HK, Wong E, et al. The six-minute walk test in healthy children: reliability and validity. Eur Respir J. 2005;25:1057-60.

11. Morales-Blanhir JE, Vidal CDP, Romero MJR, Castro MMG, Villegas AL, Zamboni M. Teste de caminhada de seis minutos: uma ferramenta valiosa na avaliação do comprometimento pulmonar. J Bras Pneumol. 2011;37:110-7.

12. Baillot A, Baillargeon JP, Brown C, Poder T, Langlois MF. The 6min walk test reflects functional capcity in primary care and obeses patients. J Sports Med. 2015;36:503-9.

13. American Thoracic Society. ATS Statement: Guidelines for the Six-Minute Walk Test. Am J Respir Crit Care Med. 2002;166:111. 7.

14. Ha F, Toukhsati SR, Sheed A, Cropper P, Moncur L, Freijah I, Hare $D L$. The benefits of a 6 minute walk test on exercise confidence are not sustained long-term in chronic heart failure patients. Circulation. 2017; 136(1)a:54-60.

15. Meneghello RS, Araújo CG, Stein R, Mastrocolla LE, Albuquerque PF, Serra SM, et al. III Diretrizes da Sociedade Brasileira de Cardiologia sobre teste ergométrico. Arq Bras Cardiol. 2010;95 5 supl 1:1-26.

16. Herdy AH, Uhnlerdorf D. Reference values for cardiopulmonary exercise testing for sedentary and active men and women. Arc Bras Cardiol. 2011;96:54-9.

17. Herdy AH, Ritt LEF, Stein R, Araújo CGS, Milani M, Meneghelo RS, et al. Teste cardiopulmonar de exercício: fundamentos, aplicabilidade e interpretação. Arq Bras Cardiol. 2016;107: 467-81.

18. Cerrone LA, Poli VFS, Sanches RB, Silva SGA, Fidalgo JPN, Nascimento MA, et al. Terapia interdisciplinar e a diminuição da sobrecarga cardiovascular em obesos. Int J Cardiovasc Sci. 2017;30:128-35.

19. Bakane PP, Zakiuddin KS. Analysis of bicycle ergometer: A Review. Int J Emerging Technol Adv Eng. 2013;3(5):785-90.

20. Shvartz E, Reibold RC. Aerobic fitness norms for males and females aged 6 to 75 years: a review. Aviat Space Environ Med. $1990 ; 61: 3-11$

21. Cooper CB, Storer TW. Teste ergometrico. Aplicações práticas e interpretação. Rio de Janeiro, Revinter. 2005.

22. Meneghello RS, Araújo CG, Stein R, Mastrocolla LE, Albuquerque PF, Serra SM, et al. III Diretriz da Sociedade Brasileira de Cardiologia sobre Teste Ergométrico. Arq Bras Cardiol. 2010;95(5):1-26.

23. Sheffield L, Holt JH, Reevers TJ. Exercise graded by heart rate in electrocardiographic testing for angina pectoris. Circulation. 1965;32:622-9.

24. Neder AJ, Nery LE. Teste de Exercício Cardiopulmonar. Jornal de Pneumologia. 2002;28 Supl 3:166-206. 
25. Stein R. Teste cardiopulmonar de exercício: noções básicas sobre o tema. Revista da Sociedade de Cardiologia do Rio Grande do Sul. 2006;15:1-4.

26. Balady GJ, Arena R, et al. Clinician's Guide to cardiopulmonary exercise testing in adults: a scientific statement from the American Heart Association. Circulation. 2010;122:191-225.

27. Loureiro BM, Feitosa-Filho GS. Escores de risco perioperatório para cirurgias não-cardíacas: descrições e comparações Perioperative risk scores for non-cardiac surgery: descriptions and comparisons. Rev Soc Bras Clin Med. 2014;12:314-20.

28. Gualandro DM, Yu PC, Calderaro D, Marques AC, Pinho C, Caramelli B, et al. II Diretriz de Avaliação Perioperatória da Sociedade Brasileira de Cardiologia. Arq Bras Cardiol. 2011;96 3 supl.1:1-68.

29. Baillot A, Vibarel-Rebot N, Lecoq A, Chadenas D. Six-minute walking test in obese female: reproducibility, relative intensity and relationship with quality of life. Sci Sports. 2009;24: 1-8.

30. Berialt K, Carpentier AC, Gagnon C, Menard J, Baillargeon JP, Ardilouze JF, et al. Reproducibility of the 6-minute walk test in obese adults. Int J Sports Med. 2009;30:725-7.

31. Baillot A, Baillargeon JP, Brown C, Poder T, Langlois MF. The 6min walk test reflects functional capacity in primary care and obeses patients. J Sports Med. 2015;36:503-9.

32. Di Thommazo-Luporini I, Carvalho PI, Luporini RI, Trimer R, Pantoni CBF, Catai AM, et al. The six-minute step test as a predictor of cardiorespiratory fitness in obese women. Eur J Phys Rehabil Med. 2015;51:793-802.

33. Haddad S. Ergometria de Membros Superiores. Um Método Importante na Avaliação Cardiocirculatória ao Exercício. Arq Bras Cardiol. 1997;69:189-93.
34. American Thoracic Society ATS/ACCP Statement on cardiopulmonary exercise testing. Am J Respir Crit Care Med. 2003;167(2):211-77.

35. Carvalho LP, Thommazo-Luporin, Aubertin-Leheudre M, Bonjorno Junior JC, Oliveira CR, Luporini RL, et al. Prediction of cardiorespiratory fitness by the six-minute step test and its association with muscle strength and power in sedentary obese and lean young women: a cross-sectional study. PLoS One. 2015;10:1-16.

36. Mendes TAB, Andreoli PBA, Cavalheiro LV, Telerman C, Laselva C. Adequação do uso do oxigênio por meio da oximetria de pulso: um processo importante de segurança do paciente Adjustment of oxygen use by means of pulse oximetry: an important tool for patient safety. Einstein. 2010;8:449-55.

37. Pedersen T, Dyrlund Pedersen B, Moller AM. Pulse oximetry for perioperative monitoring (Cochrane Review). In: The Cochrane Library. Issue 1; 2007.

38. Reed C. Care of postoperative patients with pulmonary edema. J Perianesth Nurs. 1996;11:164-9.

39. Lavie CJ, McAuley PA, Church TS, Milani RV, Blair SN. Obesity and cardiovascular diseases: implications regarding fitness, fatness, and severity in the obesity paradox. J Am Coll Cardiol. 2014;63:1345-54.

40. Veja GL. Results of expert meetings: obesity and cardiovascular disease. Obesity, the metabolic syndrome, and cardiovascular disease. Am Heart J. 2001;142:1108-16.

41. Dietrch DF, Ackermann-Liebrich U, Schindler C, Barthélémy JC, Brändli O, Gold DR, et al. SAPALDIA Team. Effect of physical activity on heart rate variability in normal weight, overweight and obese subjects: results from the SAPALDIA study. Eur J Appl Physiol. 2008;104:557-65. 